\title{
Identification of sensitive indicators to assess the interrelationship between soil quality, management practices and human health
}

\author{
R. Zornoza ${ }^{1}$, J. A. Acosta ${ }^{1}$, F. Bastida ${ }^{2}$, S. G. Domínguez ${ }^{1}$, D. M. Toledo ${ }^{3}$, and A. Faz ${ }^{1}$ \\ ${ }^{1}$ Sustainable Use, Management and Reclamation of Soil and Water Research Group. Department of Agrarian \\ Science and Technology, Universidad Politécnica de Cartagena, Paseo Alfonso XIII, 48, \\ 30203 Cartagena, Spain \\ ${ }^{2}$ Department of Soil and Water Conservation, CEBAS-CSIC, Campus Universitario de Espinardo, \\ 30100 Murcia, Spain \\ ${ }^{3}$ Cátedra de Edafología, Departamento de Suelo y Agua, Facultad de Ciencias Agrarias, Universidad Nacional \\ del Nordeste, Sargento Cabral 2131, 3400 Corrientes, Argentina \\ Correspondence to: R. Zornoza (raul.zornoza@upct.es)
}

Received: 25 August 2014 - Published in SOIL Discuss.: 25 September 2014

Revised: 17 December 2014 - Accepted: 21 January 2015 - Published: 6 February 2015

\begin{abstract}
Soil quality (SQ) assessment has long been a challenging issue, since soils present high variability in properties and functions. This paper aims to increase the understanding of SQ through the review of SQ assessments in different scenarios providing evidence about the interrelationship between SQ, land use and human health. There is a general consensus that there is a need to develop methods to assess and monitor SQ for assuring sustainable land use with no prejudicial effects on human health. This review points out the importance of adopting indicators of different nature (physical, chemical and biological) to achieve a holistic image of SQ. Most authors use single indicators to assess SQ and its relationship with land uses - soil organic carbon and $\mathrm{pH}$ being the most used indicators. The use of nitrogen and nutrient content has resulted sensitive for agricultural and forest systems, together with physical properties such as texture, bulk density, available water and aggregate stability. These physical indicators have also been widely used to assess SQ after land use changes. The use of biological indicators is less generalized, with microbial biomass and enzyme activities being the most selected indicators. Although most authors assess SQ using independent indicators, it is preferable to combine some of them into models to create a soil quality index (SQI), since it provides integrated information about soil processes and functioning. The majority of revised articles used the same methodology to establish an SQI, based on scoring and weighting of different soil indicators, selected by means of multivariate analyses. The use of multiple linear regressions has been successfully used for forest land use. Urban soil quality has been poorly assessed, with a lack of adoption of SQIs. In addition, SQ assessments where human health indicators or exposure pathways are incorporated are practically inexistent. Thus, further efforts should be carried out to establish new methodologies to assess soil quality not only in terms of sustainability, productivity and ecosystem quality but also human health. Additionally, new challenges arise with the use and integration of stable isotopic, genomic, proteomic and spectroscopic data into SQIs.
\end{abstract}




\section{Introduction}

\subsection{Concept of soil quality}

Soil is a complex environmental medium with high heterogeneity where solid, liquid and gaseous components interact within a multitude of physical, chemical and biological interrelated processes. Soil provides ecosystem services (benefits people obtain from the soil) such as food, water, timber, and fiber; regulating services that affect climate, floods, disease, waste and water quality; cultural services that provide recreational, aesthetic and spiritual benefits; and supporting services such as nutrient cycling (Millennium Ecosystem Assessment, 2005). Nonetheless, owing to unsustainable land uses, soil is degrading by loss of organic matter, salinization/alkalinization, compactness, structural destruction, sealing, contamination, acidification, etc., compromising the maintenance of further productivity. Thus, there is a tendency towards preservation of soils to promote its sustainable use (Blum, 2003). Because of the intrinsic association between soil and economy, several economic activities depend on soil quality, which include agriculture, forestry, industry and tourism, which could benefit from establishment of methods for soil quality assessments (Bone et al., 2010).

The definition of soil quality (SQ) has long been a challenging issue, since soils present high variability in properties, characteristics and functions. To our knowledge, the first user of the concept was Alexander (1971), who recommended the establishment of SQ criteria (Bone et al., 2010). Subsequent to that, several definitions were also created (e.g., Larson and Pierce, 1991; Parr et al., 1992; Doran and Parkin, 1994; Harris et al., 1996). The most integrative definitions are those established by Doran and Parkin (1994) and Harris et al. (1996), who defined SQ as the capacity of a soil to function within the limits of use, landscape and climate (ecosystem) to protect air and water quality, and to sustain productivity and plants, animals and human health. Nonetheless, despite the different definitions for SQ, there is no general consensus yet, likely due to the innate difficulty of definition of soil (Carter, 2002).

This paper aims to provide new insights through the review of soil quality assessments in different scenarios linked to forest management, agricultural management, urban systems and land use changes. The selection of indicators or indices to assess soil quality in an effective and sensitive way in terms of the ecological ambient and the purpose of the assessment is synthesized. Major concerns about the effect of land use or management are incorporated to select suitable indicators, providing evidence about the interrelationship between soil quality, environmental quality and human health.

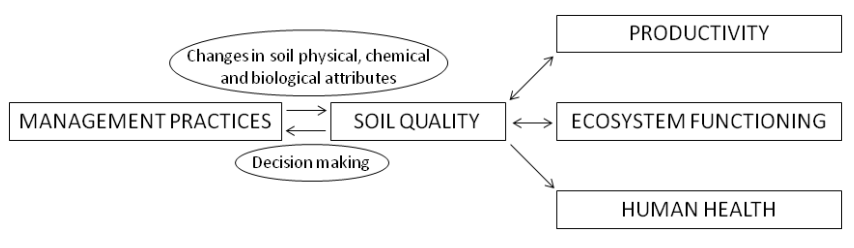

Figure 1. Interconnection between management practices, soil quality, productivity, environmental functions and soil health. Only indirect effects of management practices on other components through soil quality are taken into consideration.

\subsection{Interrelationship between soil quality, land management and human health}

Management practices in agriculture, forestry or urban environments can have negative or positive impacts on SQ, favoring the exhaustion of nutrients, loss of SOM, pollution, biodiversity reduction, etc., or favoring trends in the opposite direction. Suitable management practices for each land use within each geographical area are essential to preserve soil functions and thus promote SQ. Additionally, there is always a feedback interaction between SQ and the management practice selected, since modifications in SQ could also warn the land manager to change a practice which is no longer suitable or needed.

Less attention has been given to soil degradation and its direct or indirect effects on human health, despite the fact that SQ deterioration may possibly lead to a variety of human diseases (Deng, 2011). Bone et al. (2010) suggested that this is because the links to human health are not evident for soil to the same extent as for water and air. To assess the effects of SQ on organisms, soil quality standards (SQSs) are normally developed, which represent the concentration of a chemical or group of chemicals or pathogen in soil that should not be exceeded in order to prevent harmful effects (Rodríguez and Lafarga, 2011).

Thus, SQ has interconnections with management practices, productivity and other ecosystem aspects, showing an interdependence controlled by feedback mechanisms. SQ is also connected to human health since soil can act as source and/or pathway of disease vectors. Management practices can directly affect productivity, ecosystem functioning and human health, as well as indirectly through shifts in SQ (Fig. 1). Doran (2002) postulated that soil management practices are primary determinants of SQ, and SQ indicators must not only identify the condition of the soil resource but also define the economic and environmental sustainability of land management practices. One of the greatest challenges for researchers is "translating science into practice" through identifying soil indicators capable of showing rapid changes in the performance of an ecosystem, needed by land managers and decision makers to assess the economic, environmental, social and health impacts of management practices. 


\subsection{Approaches to assess soil quality and the selection of suitable indicators}

There is increasing acknowledgement and international interest in developing methodologies to characterize and define management practices which control degradation and enhance SQ. A methodology is necessary to select indicators to assess SQ with the aim of identifying problems in productivity, monitoring changes in ecosystem sustainability, tracking ecological effects after land use changes or reducing risks to human health. Although many studies have been conducted on SQ assessment, there is not a general methodology to characterize SQ and define a set of indicators. SQ indicators are measurable properties or characteristics which provide information about the ability of the soil to provide essential environmental services. Those attributes most sensitive to management practices or land use changes are the most adequate as indicators (Arshad and Martin, 2002). A wide range of physical, chemical and biological properties are available to be measured on a routine basis, but due to the impossibility of considering them all, it is necessary to make a selection. Larson and Pierce (1991) (cited in Larson and Pierce, 1994) suggested a minimum data set (MDS) for SQ assessment, with the objective of standardizing methodologies and procedures at an international level. This list was later extended, including biological properties by Doran and Parkin (1994). These proposals were further adapted, modified or extended in posterior studies. Physical properties reflect limitation for the development of roots, seedling emergence, infiltration, water retention or movement of fauna (Burger and Kelting, 1999). The chemical condition affects the soil-plant relations, water quality, buffering capacity, availability of nutrients and contaminants (Muckel and Mausbach, 1996). Biological indicators are more sensitive and rapidly respond to perturbations and changes in land use; soil organisms, in addition, play a direct role in the ecosystems processes, mainly in nutrient recycling and soil aggregation (Doran and Zeiss, 2000; Rillig, 2004). The selection of indicators of different nature (physical, chemical and biological) is essential to achieve a holistic image of SQ (Nannipieri et al., 1990).

Even though most authors assess SQ using different independent indicators, others prefer their combination into models or expressions in which various properties are involved (Fig. 2). These expressions are called soil quality indices (SQI), which can help in determining SQ trends and thereby indicate whether one or more changes in practice are necessary (Karlen et al., 2001). Despite computer modeling simplifying this process, novel approaches that recognize relationships among highly disparate types of data associated with SQ are needed to assess the value of different indicators for guiding land management decisions. In recent years a new approach has emerged for integrating great amounts of data, the artificial neural networks, which extract and recognize patterns in relationships among descriptive variables

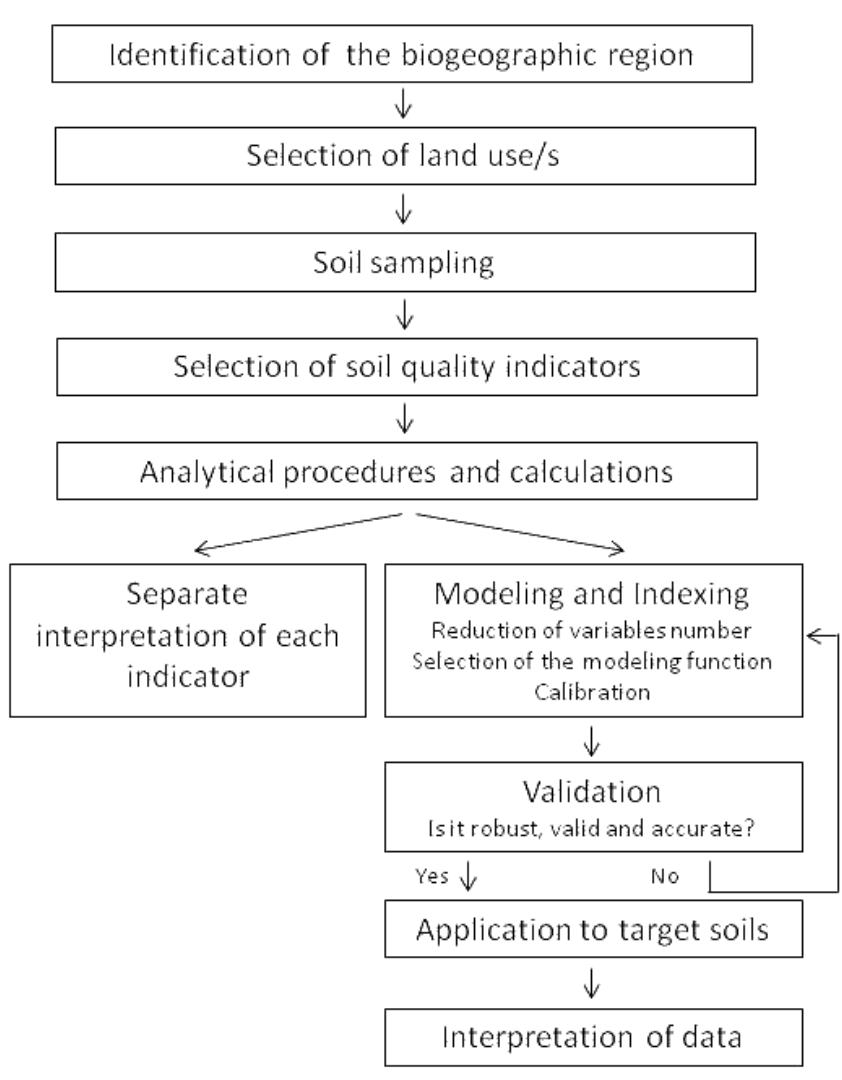

Figure 2. Flowchart of steps involved in soil quality assessment.

and are used to predict specific outputs variables (Mele and Crowley, 2008).

\section{Agricultural practices and soil quality indicators}

SQ has been assessed in agricultural systems in different agroclimatic regions and soil types under different crops and management practices. Even though crop productivity is the main concern in agriculture due to economic issues, there is a need to maintain SQ to preserve global sustainability. Assessment of SQ is needed to identify problems in production areas and to assist in formulation and evaluation of realistic agricultural and land use policies (Doran, 2002).

Soil organic carbon (SOC) has been suggested as the most important single indicator of SQ and agricultural sustainability since it affects most soil properties (Reeves, 1997; Arias et al., 2005). In the literature reviewed, SOC is the most used indicator for SQ assessments, followed by $\mathrm{pH}$, electrical conductivity (EC) and nutrients (indicators of soil fertility) (Table 1). Physical indicators have been applied in about $70 \%$ of the reviewed literature, with particle size, aggregates stability and bulk density being the most common used. About $50 \%$ of the authors incorporated biological properties, mainly microbial biomass carbon (MBC) or nitrogen (MBN) and enzymatic activities, probably owing to its high sensitivity and 
ease of measuring. Fewer studies (around $40 \%$ of the consulted literature) included organisms like earthworms and arthropods as indicators, even though they respond sensitively to land management practices (Doran and Zeiss, 2000), likely because they are useful only at a local scale (Rousseau et al., 2013).

Despite the fact that most authors assess SQ by analysis and description of single indicators, others consider the importance of an SQI to relate SQ to crop production and management practices. The majority of revised articles used the same methodology to establish an SQI, based on scoring and weighing different soil indicators (Hussain et al., 1999; Andrews and Carroll, 2001). A MDS was used to create the index, being selected in most cases by means of multivariate analyses (such as principal component analysis (PCA)). The most common parameters used were $\mathrm{pH}, \mathrm{EC}, \mathrm{SOC}$, total nitrogen (Nt) and available P. Other indicators such as $\mathrm{NO}_{3}^{-}$, $\mathrm{NH}_{4}^{+}, \mathrm{Na}, \mathrm{K}, \mathrm{Ca}, \mathrm{Mg}$, bulk density, sand, silt, clay and available water content have also been used by various authors. After indicators have been transformed using a linear or nonlinear scoring curve into unitless values and then weighted, SQIs are normally calculated using the integrated quality index equation (IQI) (Doran and Parkin, 1994) or the Nemoro quality index equation (NQI) (Qin and Zhao, 2000) by summation of the weighted scored indicators. Qi et al. (2009) measured 14 chemical indicators (SOC, $\mathrm{Nt}, \mathrm{pH}$, cation exchange capacity (CEC) and several nutrients) and compared the IQI and NQI in combination with three methods for indicator selection: total data set (TDS), MDS, and Delphi data set (indicators selected by the opinion of experts). They concluded that results were similar regardless of the method or model applied. Rahmanipour et al. (2014) compared two sets of indicators - TDS (composed of 10 physical and chemical properties, mainly the erodibility factor, $\mathrm{pH}, \mathrm{EC}, \mathrm{SOC}, \mathrm{CEC}$ and heavy metals) and MDS (indicators reduced by PCA) and two different indices: IQI and NQI. These authors concluded that an IQI/MDS approach was the most suitable tool to evaluate the effects of land management practices on SQ.

D'Hose et al. (2014) assessed the relationship between SQ and crop production under different management practices by the adoption of the IQI, using five soil indicators selected by PCA (SOC, Nt, earthworms, nematodes and MBC). These authors concluded that SQ was higher when farm compost was applied and SOC was pointed out as the most important indicator influencing crop production. Liu et al. (2014a) calculated an SQI in acid sulfate paddy soils with different productivity. They scored five soil chemical and biochemical indicators after their selection by PCA ( $\mathrm{pH}, \mathrm{Nt}, \mathrm{MBC}, \mathrm{Si}$ and $\mathrm{Zn}$ ), which were integrated into an index, showing lower SQ in systems with low productivity. Liu et al. (2014b) validated their SQI (Liu et al., 2014a) in low-productivity albic soils from eastern China, and observed significant correlations between the SQI and crop yield.
Merrill et al. (2013) assessed SQ in two different soil types sampled at different depths. For these purposes, the authors made use of the Soil Management Assessment Framework (SMAF), a pre-established SQI (Andrews et al., 2004) which evaluates SQ on the basis of critical soil functions. The authors highlighted that soil surface and subsurface properties should be integrated for SQ assessments. Li et al. (2014) also used the SMAF to assess SQ in agrosystems where mulch was added, concluding that $\mathrm{MBC}$ and $\beta$-glucosidase activity were the most responsive indicators to mulching and production systems.

There have been fewer attempts to calibrate SQIs based on other methodologies. For instance, García-Ruiz et al. (2008) established an SQI by the calculation of the geometric mean of several enzyme activities (GMea). Soil enzymes and the GMea were suitable to discriminate between a set of organic and comparable conventional olive oil orchard crops.

\section{Forest management and soil quality indicators}

About $31 \%$ of the world's land surface is covered by forests (FAO, 2012), which provide different goods and services, such as water reservoirs, biodiversity, carbon sequestration, timber, gum, recreation, etc. Previous research mainly focused on the assessment of SQ to promote highest forest productivity. Nonetheless, in recent years, international environmental concern about forest management has experienced a shift in research focus towards the sustainability of the forest ecosystem functions.

In order to assess forest $\mathrm{SQ}$, the most used indicators are SOC, followed by $\mathrm{pH}$, nutrient levels, $\mathrm{MBC}$ and mineralizable N (Table 1). Miralles et al. (2009) observed that most soil properties measured in forest soils from southeastern Spain were highly correlated with SOC. They established SQ indicators consisting of ratios to SOC, which inform about the specific activity (per $\mathrm{C}$ unit) or performance of the organic matter, independently of its total content. These authors concluded that these ratios are more effective for assessing SQ since they provide information about soil resilience. Physical attributes have been used in about $23 \%$ of the reviewed literature, with water availability or water holding capacity (WHC), soil porosity and aggregate stability being the most common indicators. In the recent years, there has been a general concern about the importance of soil biological indicators and their ecological relevance for assessing SQ, and some authors have included microbial indicators such as microbial community composition in their studies (Zornoza et al., 2009; Banning et al., 2011; Blecker et al., 2012). The adoption of SQIs under forest use has been less developed than for agroecosystems. Most authors have applied simple ratios, such as $\mathrm{C} / \mathrm{N}$, the metabolic quotient or $\mathrm{qCO}_{2}$ (soil respiration to MBC), enzyme activities / microbial biomass, SOC and N stratification ratios, $\mathrm{MBC} / \mathrm{SOC}, \mathrm{MBN} / \mathrm{Nt}, \mathrm{ATP} / \mathrm{MBC}$, er- 


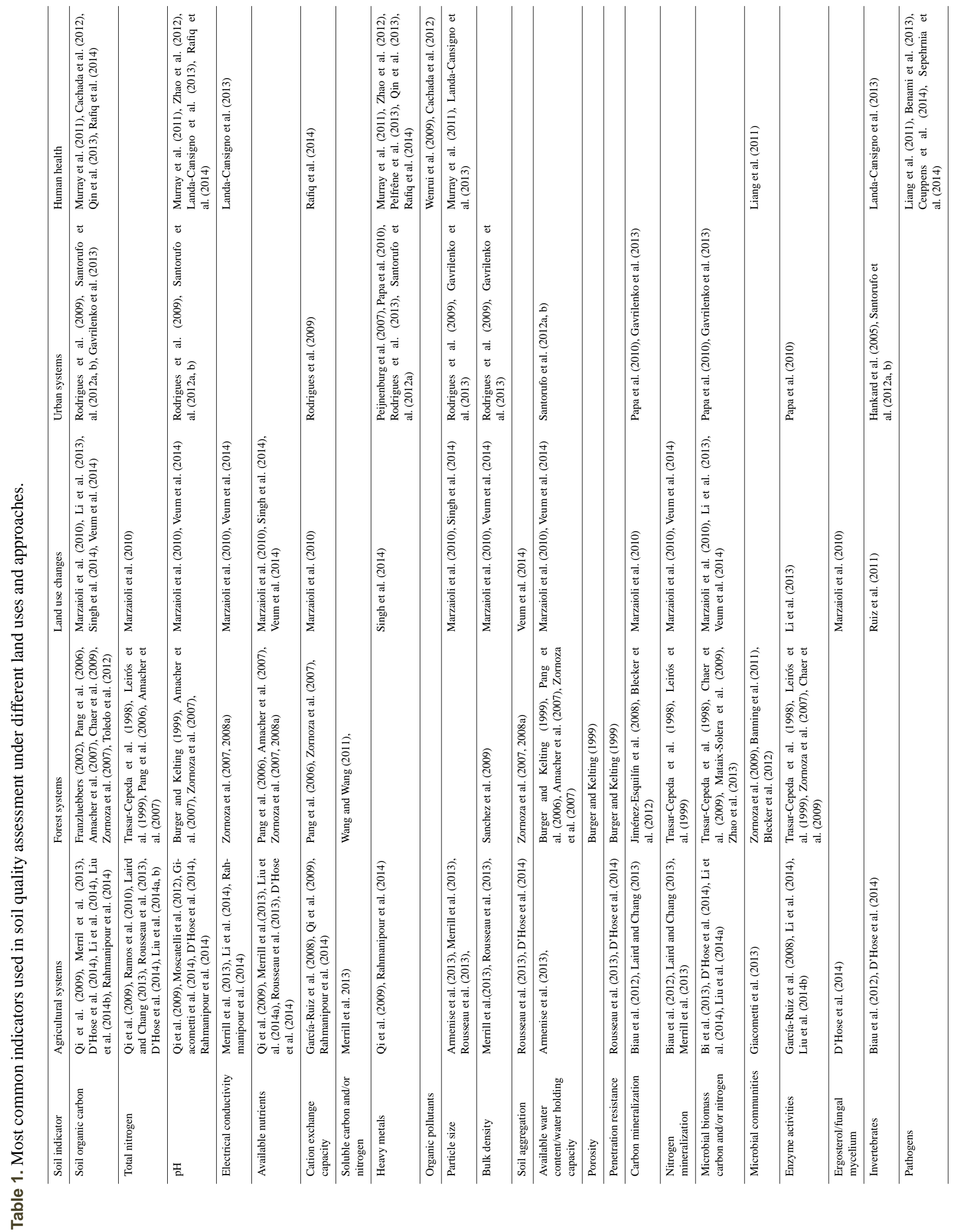


gosterol / MBC, or fungal / bacteria biomass (Trasar-Cepeda et al. 1998; Franzluebbers, 2002; Dinesh et al., 2003; MataixSolera et al., 2009; Toledo et al., 2012; Zhao et al., 2014). However, using only two soil indicators to create an SQI does not provide enough information about soil processes and functioning. Despite this fact, the development of algorithms in which different indicators are combined, has not been generalized, likely because they are limited to the area and situation in which they have been described (Gil-Sotres et al., 2005).

Burger and Kelting (1999) provided an index to assess the net effect of forest management using different soil physical, chemical and biological indicators such as porosity, available water capacity, $\mathrm{pH}, \mathrm{SOC}$ or respiration. They applied the principles proposed by Gale et al. (1991), and the SQI was calculated as the summation of five weighted indicators (sufficiency for root growth; water supply; nutrient supply; sufficiency for gas exchange; and biological activity). TrasarCepeda et al. (1998) obtained a biochemical SQI using natural soils under climax vegetation where $\mathrm{Nt}$ can be estimated by means of multiple linear regression using $\mathrm{MBC}$, mineralizable $\mathrm{N}$ and enzyme activities as independent variables. This index was validated by Leirós et al. (1999) in soils disturbed by contamination and tillage, concluding that it can be used for the rapid evaluation of soil degradation, since it distinguished between high-quality soils, soils in a transient status, and degraded soils. This methodology, based on the calculation of a soil property via multiple regressions, which suggests a balance among soil properties, has also been used by other authors. Zornoza et al. (2007) obtained, under semiarid Mediterranean conditions, two SQIs to assess soil degradation by estimation of SOC through linear combination of physical, chemical and biological indicators (pH, CEC, aggregate stability, WHC, EC and enzyme activities). These indices were further validated by Zornoza et al. (2008a) in 11 undisturbed forest soils, confirming their viability and accuracy. Chaer et al. (2009) calibrated an SQI using multiple linear regressions with SOC as a combination of MBC and phosphatase activity, confirming previous evidence of a balance in soil properties in undisturbed soils, this balance being disrupted after perturbations.

Pang et al. (2006) established an integrated fertility index (IFI) in forest soils from China with the objective of detecting changes in soil fertility in relation to vegetation, climate and disturbance practices. They applied PCA to 14 physical and chemical indicators, and calculated a value for each identified PC as the summation of each indicator value multiplied by its loading. The IFI was calculated as the summation of each weighted PC. The authors found that IFI was highly correlated with tree growth.

Amacher et al. (2007) developed an SQI that integrated 19 physical and chemical properties (bulk density, water content, $\mathrm{pH}, \mathrm{SOC}$, inorganic $\mathrm{C}, \mathrm{Nt}$ and nutrients) with the aim of creating a tool for establishing baselines and detecting forest health trends in USA. These authors arranged each soil indicator into different categories, selecting threshold levels according to its functional significance in soil, and assigned an individual index value for each category. For instance, SOC $<1 \%$ was assigned an index value of 0 , while SOC $>5 \%$ was assigned an index value of 2 . The SQI is then calculated as the summation of all individual soil property index values. Contrary to the common procedure, these authors did not reduce the quantity of indicators before calculating the SQI, which greatly contributes to reducing time and resources. The authors strongly recommend the measurement of the 19 selected soil properties, since using less quantity could provide a distorted assessment of soil quality.

\section{Land use changes and soil quality}

Changes in land use are human-derived impacts with high affection in ecosystem functioning. Land uses have a strong impact on the level of SOC, which has been widely used as indicator of SQ (Table 1). Overall, soil management that leads to an accumulation of SOC is related to ecosystem benefits. However, land misuse can cause degradation of soil as a consequence of reducing SOC levels (Lal, 2004). Land conversion from native forest to cropland is prone to soil $\mathrm{C}$ losses (Camara-Ferreira et al., 2014). Conversion of croplands to grasslands has been elucidated as a successful approach for C sequestration (Chen et al., 2009). Albaladejo et al. (2013) studied the effect of climate with regards to land use in southeastern Spain. These authors concluded that $\mathrm{C}$ sequestration in cropland through appropriate land management can be suitable when forestland is limited by bedrock surfaces. Gelaw et al. (2014) revealed that conversion of Ethiopian croplands to grasslands or integration of appropriate agroforestry trees in cropping fields has a huge potential for $\mathrm{C}$ sequestration. Agroforestry, the practice of growing trees and crops in interacting combinations on the same unit of land, can be proposed as a promising strategy for $\mathrm{C}$ sequestration with special emphasis on arid and semiarid areas that are usually degraded by SOC losses.

Microbial biomass and enzyme activity have been widely used to assess impacts of land use changes on SQ. In Brazilian semiarid ecosystems, Nunes et al. (2012) reported that MBC was highly sensitive to shifts in land use. Mijangos et al. (2014) observed that replacing meadows with pine plantations under a temperate climate influences enzyme activities and nutrient cycling. Moreover, enzyme activity was sensitive to human-induced alterations in a land use sequence from natural forest pastures and shrublands (Tischer et al., 2014). Zhao et al. (2013) evaluated natural forest, park, agriculture, street garden and roadside tree land uses using MBC and microbial functional diversity as indicators. In comparison to forest, MBC was lower for the rest of land uses but functional diversity was higher in the roadside-tree soils.

The simple index most used in the reviewed literature is the $q \mathrm{CO}_{2}$. This ratio has resulted a suitable indicator to pro- 
vide evidence of soil perturbation after deforestation or other land use changes (Dilly et al., 2003; Bastida et al., 2006a). The establishment of multiparametric indices has been used as an adequate tool for integrating greater information of soil quality, and some of them have been recently applied to assess the impact of land use changes on SQ. Veum et al. (2014) evaluated SQ of perennial vegetation plots in comparison to agricultural soils under no tillage or conventionally treated plots, using for these purposes the SMAF with indicators such as aggregate stability, bulk density, EC, $\mathrm{pH}, \mathrm{SOC}, \mathrm{MBC}$, mineralizable $\mathrm{N}$ and nutrients. SQ was greatest under native, perennial vegetation, and declined with increasing levels of soil disturbance resulting from cultivation.

Singh et al. (2014) selected indicators from a data set of 29 soil properties by PCA and produced an SQI which indicated that SQ in the natural forest land and grasslands was higher than in the cultivated sites. Interestingly, these authors highlighted that SOC and exchangeable $\mathrm{Al}$ were the two most powerful indicators of SQ in the eastern Himalayan region of India. Ruiz et al. (2011) elaborated an index of biological soil quality (IBSQ) based on macroinvertebrates and concluded that well-managed crops and pastures may have better SQ than some forests.

Marzaioli et al. (2010) established an SQI (without minimum data set selection) using physical, chemical and biological indicators such as aggregate stability, WHC, bulk density, particle size, $\mathrm{pH}, \mathrm{EC}, \mathrm{CEC}, \mathrm{SOC}, \mathrm{Nt}$, nutrients, MBC, respiration and fungal mycelium. The authors observed a low SQ in almost all permanent crops; an intermediate SQ in shrublands, grazing lands, coniferous forest and middle-hill olive grove; and a high SQ in mixed forests.

$\mathrm{Li}$ et al. (2013) measured the impact of human disturbances in SQ, developing an SQI based on Bastida et al. (2006b). The SQI was evaluated in alpine grasslands with different levels of degradation, based on plant cover, production, proportion of primary plant and height of the plant. Fifteen indicators (chemical, physical and biological) were used to build up the SQI after selection of a MDS by PCA. Indicators related to nitrogen cycling (urease, $\mathrm{MBN} / \mathrm{Nt}$, proteinase) and SOC were found to be the most sensitive indicators.

\section{Urban management and soil quality indicators}

Soil is an essential element in urban ecosystems (Luo et al., 2012). However, urban soil receives a major proportion of pollutants from industrial, commercial and domestic activities (Cheng et al., 2014). Therefore, urban SQ must be included in urban management practices by selection of appropriate indicators (Vrscaj et al., 2008). Since pollution is the factor which drives the most intense degradation in urban environments (Zhang et al., 2003), most research has dealt with the distribution and dispersion of pollutants (Davidson et al., 2006; Rodrigues et al., 2006; Wong et al.,
2006; Szolnoki et al., 2013). Urban soil pollution is normally assessed by relating pollutant levels to the environmental guidelines, or by establishment of different simple indices. In this context, several simple indices have been developed and applied in urban soil for heavy metal pollution (Muller, 1969; Sutherland, 2000): a geo-accumulation in$\operatorname{dex}\left(I_{\mathrm{geo}}=\log _{2}\left[C_{i} / 1.5 B_{i}\right]\right)$, pollution index $\left(\mathrm{PI}=C_{i} / B_{i}\right)$, integrated pollution index (IPI $=\Sigma \mathrm{PI} / n)$, enrichment factor $\left(\mathrm{EF}_{i}=\left[C_{i}-\right.\right.$ sample $/ C_{\text {ref }}-$ sample $] /\left[B_{i}-\right.$ background $/ B_{\text {ref }}-$ background]), where $n$ is the number of measured elements, $C_{i}$ (sample) is the metal concentration $(i), B_{i}$ (background) is the baseline concentration, $C_{\text {ref }}$ (sample) is the content of the reference element in the sample and $B_{\text {ref }}$ is the content of the reference element in the reference soil. However, metals can be present in soils with different speciation, and so with different bioavailability and solubility. Hence, to assess urban SQ, the soluble or bioavailable fractions of the metals should be taken into account besides total concentrations (Rodrigues et al., 2013). There are several methods based on single or sequential schemes of chemical extraction to determine the availability of metals in urban soils ( $\mathrm{Li}$ et al., 2001).

Besides heavy metals, other indicators such as particle size distribution, SOC, $\mathrm{pH}$ and CEC should be included in urban SQ studies to integrate soil functions with pollution effects (Pouyat et al., 2008). Rodrigues et al. (2009) studied the influence of metal concentration and soil properties on urban SQ. These authors concluded that the concentrations of metals are not the dominant factor controlling variability in $\mathrm{SQ}$, and soil texture, $\mathrm{pH}$ and SOM must be considered to affect this variability, which has often been ignored in urban systems. Papa et al. (2010) determined urban SQ evaluating the influence of soil trace metal concentrations in relation to distance from urban roads on $\mathrm{MBC}$, respiration and eight enzyme activities, observing a negative relationship between microbial activity and metal concentration. Santorufo et al. (2012a) assessed urban SQ by integrating chemical and ecotoxicological approaches. They revealed that the toxicity to invertebrates seemed to be related to heavy metals, since the largest effects were found in soils with high metal concentrations. However, SOC and $\mathrm{pH}$ played an important role in mitigating the toxicity of metals. Santorufo et al. (2012b) studied soil invertebrates as bioindicators of urban SQ, being the community more abundant and diverse in the soils with high SOM and water content and low metal concentrations. The taxa more resistant to the urban environment included Acarina, Enchytraeidae, Collembola and Nematoda. Gavrilenko et al. (2013) used the soil-ecological index (SEI), which was created for agricultural soils, to assess SQ in different ecosystems including urban areas. The SEI is a product of several indices accounting for seven physical and chemical properties and for the climatic characteristics of the region. They concluded that this SEI was correlated with MBC and thus reflects the ecological function of the soil. 


\section{Soil quality indicators directly related to human health}

Relating the state of the soil to effects on human wellbeing is a challenging task, being that it is difficult to monitor, quantify and model. Kentel et al. (2011) highlighted the importance of taking into account the human health perspective on SQ assessment. They postulated that health-risk-based decision making may help to manage associated costs and to identify priority sites with regard to health risks. This allows better allocation of available resources and identification of necessary actions that are protective of human health. Because of these reasons, traditional SQ assessment should include health-risk-based indicators such as pollutants or pathogens, taking into account the potential exposure pathways.

Since soil pollution is a threat to public health, the study of soil pollutants has been an important topic in the literature. The source-pathway-receptor pollutant linkage has been used extensively in the risk assessment of polluted soils. Risk assessment aims to characterize the potential adverse health effects of human exposures to environmental hazards (Murray et al., 2011). A potential risk exists if there is a source of pollutants, a receptor sensitive to the pollutant at the exposure level, and a pathway linking both (Bone et al., 2010). Soil can be a source of pollutants with humans as a receptor through pathways such as direct ingestion of soil particles, ingestion of plants or animals which bioaccumulated the contaminants, inhalation, and dermal contact (Collins et al., 2006; Sjöström et al., 2008). The levels of pollutants that reach humans through the above pathways are normally calculated by the use of different quotients or equations, which relate the concentration of the pollutant in soil to SQS, ingestions/inhalation/adhesion rates, body weight, exposure time or exposure frequency (Masto et al., 2011; Nadal et al., 2011; Pelfrêne et al., 2013).

Most studies about soil pollution deal with the presence of heavy metals. In the attempt to assess the mobility of trace elements and thus to quantify their transmission from soil to other organisms, the use of bioaccumulation or bioconcentration factors, which describe the concentration of an element in a biological tissue relative to the concentration in the soil, are gaining acceptance (Murray et al., 2011; Zhao et al., 2012). Even though it is not recognized as an SQI, it could be stated that soils with low bioconcentration factors are less hazardous for a population. It has been assessed that there are physicochemical soil characteristics controlling metal availability such as $\mathrm{pH}, \mathrm{SOM}$ or clay contents. Fordyce et al. (2000) identified that Se bioavailability in villages from China with high Se toxicity was controlled by $\mathrm{pH}$. Zhao et al. (2012) reported that the spatial patterns of the heavy metal concentrations and soil $\mathrm{pH}$ indicated that the areas with the highest human health risk did not directly coincide with the areas of highest heavy metal concentrations but instead with the areas of lower soil pH. Qin et al. (2013) observed that the concentration of Se in rice plants was associated with the soil fraction bound to SOM, suggesting that SOM controls Se uptake by rice and thus increases hazards to human health. Pelfrêne et al. (2011) concluded that the inclusion of bioavailability analyses during health risk assessment (fraction of pollutant that is soluble in the gastrointestinal environment and potentially available for absorption) would provide a more realistic assessment of heavy metal exposure than traditional measurements.

Very few studies treat the problem of soil organic pollution and human health, possibly due to the higher difficulty in analysis and identification, and temporal decay through physicochemical and biological processes. Wenrui et al. (2009) established the levels of different pollutants in soil and assessed the affection to the population by bioaccessibility evaluations (e.g., in vitro simulators of human digestion) or development of exposure scenarios and health hazard equations. In general, no other soil properties are measured together with the target contaminant to relate its dynamics and fate. However, Cachada et al. (2012) found that SOC was an important factor for polycyclic aromatic hydrocarbons and organochlorides retention in soils.

Despite the broad concern about soil pollution and human health, very few studies directly and explicitly relate pollution to SQ and how deterioration of SQ can affect human wellbeing (Poggio et al., 2008; Masto et al., 2011; Pelfrêne et al., 2013). Abrahams (2002), although not explicitly, related SQ and human health by stating the deleterious impacts that soil properties pose to human societies. Murray et al. (2011) reported the need to include soil characteristics, specifically SOM quantity and quality, $\mathrm{pH}$ or clay content, when setting threshold criteria for metal content under human risk evaluations. The study of Rafiq et al. (2014) was the only study dealing with health risk assessment that established SQ standards for potential dietary toxicity to humans. They observed that soil pH, CEC and SOM were the main factors which influenced the $\mathrm{Cd}$ bioavailability in different soil types.

The sanitary status of the soil is evaluated on the basis of indicator bacteria, usually Escherichia coli, faecal streptococci, Salmonella sp., Shigella sp. and the persistent sporulated Clostridium (e.g., Liang et al., 2011; Benami et al., 2013; Ceuppens et al., 2014). Some of these studies also use protozoa or helminths (e.g., Landa-Cansigno et al., 2013). All revised articles identify different taxonomic groups in soil and monitor their survival, persistence and movement with time in terms of different soil characteristics and management practices (Benami et al., 2013; Sepehrnia et al., 2014). Voidarou et al. (2011) related the presence of pathogens/parasites to SQ, indicating that a systematic monitoring of the soil ecosystems must include bacteriological parameters to obtain information adequate for assessing their overall quality. It has been reported that SOM, pH, EC and clay contents are determinant on the adsorption capacity of pathogen bacteria, protozoa or nematodes (Landa-Cansigno et al., 2013), and thus they should be considered when as- 
sessing the persistence of pathogens in soil. The complexity of the soil microbial community can also affect the survival of pathogens. Liang et al. (2011) observed that the die-off rate of $E$. coli progressively declined with the reduction of microbial community diversity.

\section{Conclusions and researchable challenges}

There is a need to develop methods to assess and monitor soil quality for assuring sustainable land use with no prejudicial effects on human health. A review of different soil quality assessment studies indicated that there is an increased concern of using indicators of different nature to assess soil quality. The most used indicators are soil organic carbon and $\mathrm{pH}$, since different management practices strongly affect their value. Total nitrogen and nutrient content are often used in agricultural and forest systems, since they provide information about the fertility of a soil, essential to supporting adequate production. Regarding physical features, particle size distribution, bulk density, available water and aggregate stability are the most widely used parameters, mainly to assess the impact of agricultural management and changes in land use on soil quality. Biological indictors are less generalized in the literature, with enzyme activities and microbial biomass being the most common indicators used on a routine basis in agricultural and forest systems. Despite the attempts to calibrate soil quality indices, the establishment of a global index for general use seems to be difficult at present due to the wide range of soils, conditions and management practices. The transformation (by linear or nonlinear scoring functions) and weighting of indicators and their summation into an index is the tool most widely used and validated in the literature for most land uses. Nonetheless, the use of multiple linear regressions has been successfully used under forest land use.

Although urban soil quality has been linked with wellbeing for city residents, it has been less studied than other soil uses, with a lack of adoption of soil quality indices. In consequence there is an urgent need to establish a framework that can be adjusted based on different management goals for urban soil quality evaluation. There is also a lack of concern about the influence of soil on human health, with the result that soil quality assessments where human health indicators or exposure pathways are incorporated are practically inexistent. Further efforts should be carried out to establish new methodologies to assess not only soil quality in terms of sustainability, productivity and ecosystems quality but also human health. This gap is mainly due to the extreme difficulty of relating a per se complicated concept as that of soil quality to soilborne diseases, owing to the vast existent pathways of exposure.

The application and development of new methodologies such as stable isotopes, genomic and proteomic tools addressing the structure of microbial communities, as well as the functionality of microbial populations in soil, might be potentially used as indicators of soil quality (Bastida et al., 2014). Spectroscopy is becoming a powerful tool in the assessment of soil quality as well, for it is accurate, inexpensive and rapid - essential attributes for the adoption of these techniques in soil quality establishment (Zornoza et al., 2008b). Nevertheless, the integration of these new parameters into soil quality index is still a challenge.

Acknowledgements. The authors would like to thank Ellena Louise Hall for improving the English writing of the manuscript.

Edited by: A. A. Berhe

\section{References}

Abrahams, P. W.: Soils: their implications to human health, Sci. Total Environ., 291, 1-32, 2002.

Albaladejo, J., Ortiz, R., García-Franco, N., Ruíz-Navarro, A., Almagro, M., García-Pintado, J., and Martínez-Mena, M.: Landuse and climate change impacts on soil organic carbon stocks in semi-arid Spain, J. Soils Sediments, 13, 265-277, 2013.

Alexander, M.: Agriculture's responsibility in establishing soil quality criteria, Environmental improvement - agriculture's challenge in the seventies, National Academy of Sciences, Washington, USA, 1971.

Amacher, M. C., O’Neil, K. P., and Perry, C. H.: Soil vital signs: A new Soil Quality Index (SQI) for assessing forest soil health, Res. Pap., RMRS-RP-65WWW, Fort Collins, CO: USDA, Forest Service, Rocky Mountain Research Station, 12 pp., available at: http://www.fs.fed.us/rm/pubs/rmrs_rp065.pdf (last access: 25 June 2014), 2007.

Andrews, S. S. and Carroll, C. R.: Designing a soil quality assessment tool for sustainable agroecosystem management, Ecol. Appl., 11, 1573-1585, 2001.

Andrews, S. S., Karlen, D. L., and Cambardella, C. A.: The soil management assessment framework: a quantitative soil quality evaluation method, Soil Sci. Soc. Am. J., 68, 1945-1962, 2004.

Arias, M. E., González-Pérez, J. A., González-Vila, F. J., and Ball, A. S.: Soil health - a new challenge for microbiologists and chemists, Int. Microbiol., 8, 13-21, 2005.

Armenise, E., Redmile-Gordon, M. A., Stellacci, A. M., Ciccarese, A., and Rubino, P.: Developing a soil quality index to compare soil fitness for agricultural use under different managements in the Mediterranean environment, Soil Till. Res., 130, 91-98, 2013.

Arshad, M. A. and Martin, S.: Identifying critical limits for soil quality indicators in agro-ecosystems, Agr. Ecosyst. Environ., 88, 153-160, 2002.

Banning, N. C., Gleeson, D. B., Grigg, A. H., Grant, C. D., Andersen, G. L., Brodie, E. L., and Murphy, D. V.: Soil Microbial Community Successional Patterns during Forest Ecosystem Restoration, Appl. Environ. Microbiol., 77, 6158-6164, 2011.

Bastida, F., Moreno, J. L., Hernández, T., and García, C.: Microbiological activity in a soil 15 years alter its devegetation, Soil Biol Biochem., 38, 2503-2507, 2006a. 
Bastida, F., Moreno, J. L., Hernández, T., and García, C.: Microbiological degradation index of soils in a semiarid climate, Soil Biol. Biochem., 38, 3463-3473, 2006b.

Bastida, F., Hernández, T., and García, C.: Metaproteomics of soils from semiarid environment: functional and phylogenetic information obtained with different protein extraction methods, J. Proteomics., 101, 31-42, 2014.

Benami, M., Gross, A., Herberg, M., Orlofsky, E., Vonshak, A., and Gillor, O.: Assessment of pathogenic bacteria in treated graywater and irrigated soils, Sci. Total Environ., 458-560, 298-302, 2013.

Bi, C. J., Chen, Z. L., Wang, J., and Zhou, D.: Quantitative Assessment of Soil Health under Different Planting Patterns and Soil Types, Pedosphere, 23, 194-204, 2013.

Biau, A., Santiveri, F., Mijangos, I., and Lloveras, J.: The impact of organic and mineral fertilizers on soil quality parameters and the productivity of irrigated maize crops in semiarid regions, Europ. J. Soil Biol., 53, 56-61, 2012.

Blecker, S. W., Stillings, L. L., Amacher, M. C., Ippolito, J. A., and DeCrappeo, N. M.: Development of vegetation based soil quality indices for mineralized terrane in arid and semi-arid regions, Ecol. Indic., 20, 65-74, 2012.

Blum, W.: European soil protection strategy, J. Soils Sediments, 3, p. 242, 2003.

Bone, J., Head, M., Barraclough, D., Archer, M., Scheib, C., Flight, D., and Voulvoulis, N.: Soil quality assessment under emerging regulatory requirements, Environ. Int., 36, 609-622, 2010.

Burger, J. A. and Kelting, D. L.: Using soil quality indicators to assess forest stand management, Forest Ecol. Manag., 122, 155166, 1999.

Cachada, A., Pato, P., Rocha-Santos, T., Ferreira da Silva, E., and Duarte, A. C.: Levels, sources and potential human health risks of organic pollutants in urban soils, Sci. Total Environ., 430, 184192, 2012.

Camara-Ferreira, A. C., Carvalho-Leite, L. F., Ferreira de Araujo, A., and Eisenhauer, N.: Land-use type effects on soil organic carbon and microbial properties in a semi-arid region of Northeast Brazil, Land Degrad. Dev., online first, doi:10.1002/ldr.2282, 2014.

Carter, M. R.: Soil quality for sustainable land management: organic matter and aggregation interactions that maintain soil functions, Agron. J., 94, 38-47, 2002.

Ceuppens, S., Hessel, C. T., de Quadros Rodrigues, R., Bartz, S., Tondo, E. C., and Uyttendaele, M.: Microbiological quality and safety assessment of lettuce production in Brazil, Int. J. Food Microbiol., 181, 67-76, 2014.

Chaer, G. M., Myrold, D., and Bottomley, P. J.: A soil quality index based on the equilibrium between soil organic matter and biochemical properties of undisturbed coniferous forest soils of the Pacific Northwest, Soil Biol. Biochem., 41, 822-830, 2009.

Chen, H., Marhan, S., Billen, N., and Stahr, K.: Soil organic-carbon and total nitrogen stocks as affected by different land uses in Baden-Württemberg (southwest Germany), J. Plant Nutr. Soil Sc., 172, 32-42, 2009.

Cheng, H. X., Li, M., Zhao, C. D., Li, K., Peng, M., and Qin, A. H.: Overview of trace metals in the urban soil of 31 metropolises in China, J. Geochem. Explor., 139, 31-52, 2014.

Collins, C., Fryer, M., and Grosso, A.: Plant uptake on non-ioninc organic chemicals, Environ. Sci. Technol., 40, 45-52, 2006.
Davidson, C. M., Urquhart, G. J., Ajmone-Marsan, F., Biasioli, M., da Costa Duarte, A., and Diaz-Barrientos, E.: Fractionation of potentially toxic elements in urban soils from five European cities by means of a harmonised sequential extraction procedure, Anal. Chim. Acta, 565, 63-72, 2006.

Deng, X.: Land Quality: Environmental and Human Health Effects, in: Reference Module in Earth Systems and Environmental Sciences, edited by: Elias, S. A., Elsevier, Amsterdam, 362-365, 2011.

D'Hose, T., Cougnon, M., De Vliegher, A., Vandecasteele, B., Viaene, N., Cornelis, W., Van Bockstaele, E., and Reheul, D.: The positive relationship between soil quality and crop production: A case study on the effect of farm compost application, Appl. Soil Ecol., 75, 189-198, 2014.

Dilly, O., Blume, H. P., Sehy, U., Jiménez, M., and Munch, J. C.: Variation of stabilised, microbial and biologically active carbon and nitrogen soil under contrasting land use and agricultural management practices, Chemosphere, 52, 557-569, 2003.

Dinesh, R., Ghoshal Chaudhuri, S., Ganeshamurthy, A. N., and Chanchal, D.: Changes in soil microbial indices and their relationships following deforestation and cultivation in wet tropical forests, Appl. Soil Ecol., 24, 17-26, 2003.

Doran, J. W.: Soil health and global sustainability: translating science into practice, Agr. Ecosyst. Environ., 88, 119-127, 2002.

Doran, J. W. and Parkin, T. B.: Defining and Assessing Soil Quality, in: Defining soil quality for a sustainable environment, edited by: Doran, J. W., Coleman, D. F., Bezdicek, D. F., and Stewart, B. A., Soil Sci. Soc. Am., Special Publication 35, Madison, WI, 3-21, 1994.

Doran, J. W. and Zeiss, M. R.: Soil health and sustainability: managing the biotic component of soil quality, Appl. Soil Ecol., 15, 3-11, 2000.

FAO: El estado de los bosques del mundo, Organización de las Naciones Unidas para la Alimentación y la Agricultura, available at: http://www.fao.org/docrep/016/i3010s/i3010s.pdf (last access: 25 June 2014), Rome, 2012.

Fordyce, F. M., Guangdi, Z., Green, K., and Xinping, L.: Soil, grain and water chemistry in relation to human selenium-responsive diseases, in: Enshi District, China, Appl. Geochem., 15, 117132, 2000.

Franzluebbers, A. J.: Soil organic matter stratification ratio as an indicator of soil quality, Soil Till. Res., 66, 95-106, 2002.

Gale, M. R., Grigal, D. F., and Harding, R. B.: Soil productivity index: predictions of site quality for white spruce plantations, Soil Sci. Soc. Am. J., 55, 1701-1708, 1991.

García-Ruiz, R., Ochoa, V., Hinojosa, M. B., and Carreira, J. A.: Suitability of enzyme activities for the monitoring of soil quality improvement in organic agricultural systems, Soil Biol. Biochem., 40, 2137-2145, 2008.

Gavrilenko, E. G., Ananyeva, N. D., and Makarov, O. A.: Assessment of Soil Quality in Different Ecosystems (with Soils of Podolsk and Serpukhov Districts of Moscow Oblast as Examples), Eurasian Soil Sci., 46, 1241-1252, 2013.

Gelaw, A. M., Singh, B. R., and Lal, R.: Soil organic carbon and total nitrogen stocks under different land uses in a semi-arid watershed in Tigray, Northern Ethiopia, Agr. Ecosyst. Environ., 188, 256-263, 2014.

Giacometti, C., Demyan, M. S., Cavani, L., Marzadori, C., Ciavatta, C., and Kandeler, E.: Chemical and microbiological soil quality 
indicators and their potential to differentiate fertilization regimes in temperate agroecosystems, Appl. Soil Ecol., 64, 32-48, 2013.

Giacometti, C., Cavani, L., Baldoni, G., Ciavatta, C., Marzadori, C., and Kandeler, E.: Microplate-scale fluorometric soil enzyme assays as tools to assess soil quality in a long-term agricultural field experiment, App. Soil Ecol., 75, 80-85, 2014.

Gil-Sotres, F., Trasar-Cepeda, C., Leirós, M. C., and Seoane, S.: Different approaches to evaluating soil quality using biochemical properties, Soil Biol. Biochem., 37, 877-887, 2005.

Hankard, P. K., Bundy, J. G., Spurgeon, D. J., Weeks, J. M., Wright, J., and Weinberg, C.: Establishing principal soil quality parameters influencing earthworms in urban soils using bioassays, Environ. Pollut., 133, 199-211, 2005.

Harris, R. F., Karlen, D. L., and Mulla, D. J.: A conceptual framework for assessment and management of soil quality and health, in: Methods for assessing soil quality, Soil Sci. Soc. Am. J., Madison, Wisconsin, USA, 61-82, 1996.

Hussain, I., Olson, K. R., Wander, M. M., and Karlen, D. L.: Adaptation of soil quality indices and application to three tillage systems in southern Illinois, Soil Till. Res., 50, 237-249, 1999.

Jiménez Esquilín, A. E., Stromberger, M. E., and Shepperd, W. D.: Soil Scarification and Wildfire Interactions and Effects on Microbial Communities and Carbon, Soil Sci. Soc. Am. J., 72, 111118,2008

Karlen, D. L., Andrews, D. D., and Doran, J. W.: Soil quality: Current concepts and applications, Adv. Agron., 74, 1-40, 2001.

Kentel, E., Aksoy, A., Büyüker, B., Dilek, F., Girgin, Ipek, M. H., Polat, S.., Yetiş, Ü., and Ünlü, K.: Challenges in Development and Implementation of Health-Risk-Based Soil Quality Guidelines: Turkey's Experience, Risk Anal., 31, 657-667, 2011.

Laird, D. A. and Chang, C. W.: Long-term impacts of residue harvesting on soil quality, Soil Till. Res., 134, 33-40, 2013.

Lal, R.: Soil carbon sequestration to mitigate global change, Geoderma, 123, 1-22, 2004.

Landa-Cansigno, O., Durán-Álvarez, J. C., and Jiménez-Cisneros, B.: Retention of Escherichia coli, Giardia lamblia cysts and Ascaris lumbricoides eggs in agricultural soils irrigated by untreated wastewater, J. Environ. Manag., 128, 22-29, 2013.

Larson, W. E. and Pierce, F. J.: Conservation and enhancement of soil quality. in: Evaluation for sustainable land management in the developing world, Vol. 2: Technical papers, edited by: Dumanski, J., Pushparajah, E., Latham, M., and Myers, R., Proc. Int. Worksh., Chiang Rai, Thailand, 15-21 Sept. 1991. Int. Board. For. Soil Res. Manage., Bangkok, Thailand, 175-203, 1991.

Larson, W. E. and Pierce, F. J.: The dynamics of soil quality as a measure of sustainable mangement, in: Defining soil quality for a sustainable environment, edited by: Doran, J. W., Coleman, D. C., Bezdicek, D. F., and Stewart, B. A., SSSA-Special Publication 35, Soil Science Society of America, Madison, WI, 37-51, 1994.

Leirós, M. C., Trasar-Cepeda, C., García-Fernández, F., and GilSotres, F. : Defining the validity of a biochemical index of soil quality, Biol. Fert. Soils, 30, 140-146, 1999.

Liang, Z., He, Z., Powell, C. A., and Stoffella, P.: Survival of Escherichia coli in soil with modified microbial community composition, Soil Biol. Biochem., 43, 1591-1599, 2011.

Li, Y., Dong, S., Wen, L., Wang, X., and Wu, Y.: Assessing the soil quality of alpine grasslands in the Qinghai-Tibetan Plateau using a modified soil quality index, Environ. Monit. Assess., 185, 8011-8022, 2013.

Li, C., Moore-Kuceraa, J., Leeb, J., Corbin, A., Brodhagen, M., Miles, C., and Inglise, D.: Effects of biodegradable mulch on soil quality, Appl. Soil Ecol., 79, 59-69, 2014.

Li, X. D., Poon, C. S., and Liu, P. S.: Heavy metal contamination of urban soils and street dusts in Hong Kong, Appl. Geochem., 16, 1361-1368, 2001.

Liu, Z., Zhou, W., Shen, J., Li, S., Liang, G., Wang, X., Sun, J., and Al, C.: Soil Quality Assessment of Acid Sulfate Paddy Soils with Different Productivities in Guangdong Province, China, J. Integ. Agric., 13, 177-186, 2014a.

Liu, Z., Zhou, W., Shen, J., Li, S., He, P., and Liang, G.: Soil quality assessment of Albic soils with different productivities for eastern China, Soil Till. Res., 140, 74-81, 2014b.

Luo, X. S., Yu, S., Zhu, Y. G., and Li, X. D.: Trace metal contamination in urban soils of China, Sci. Total Environ., 421, 17-30, 2012.

Marzaioli, R., D'Ascoli, R., De Pascale, R. A., and Rutigliano, F. A.: Soil quality in a Mediterranean area of Southern Italy as related to different land use types, Appl. Soil Ecol., 44, 205-212, 2010.

Masto, R. E., Ram, L. C., George, J., Selvi, V. A., Sinha, A. K., Verma, S. K., Rout, T. K., Priyadarshini, and Prabal, P.: Status of some soil trace elements and their potential human health risks around a coal beneficiation plant, Int. J. Coal Prep. Util., 31, 6177, 2011

Mataix-Solera, J., Guerrero, C., García-Orenes, F., Bárcenas, G. M., and Torres M. P.: Forest Fire Effects on Soil Microbiology, in: Fire Effects on Soils and Restoration Strategies, Science Publishers, Inc., 133-175, 2009.

Mele, P. M. and Crowley, D. E.: Application of self-organizing maps for assessing soil biological quality, Agr. Ecosyst. Environ., 126, 139-152, 2008.

Merrill S. D., Liebig, M. A., Tanaka, D. L., Krupinsky, J. M., and Hanson, J. D.: Comparison of soil quality and productivity at two sites differing in profile structure and topsoil properties, Agr. Ecosist. Environ., 179, 53-61, 2013.

Mijangos, I., Epelde, L., Garbisu, C., and González-Oreja, J. A.: Modification of soil enzyme activities as a consequence of replacing meadows by pine plantations under temperate climate, Pedobiologia, 57, 61-66, 2014.

Millennium Ecosystem Assessment: Ecosystems and Human Wellbeing: Synthesis, Island Press, Washington, DC, 2005.

Miralles, I., Ortega, R., Almendros, G., Sánchez-Marañón, M., and Soriano, M.: Soil quality and organic carbon ratios in mountain agroecosystems of South-east Spain, Geoderma, 150, 120-128, 2009.

Moscatelli, M. C., Lagomarsino, A., Garcillo, A. M. V., Pignataro, A., and Grego, S.: $\beta$-Glucosidase kinetic parameters as indicators of soil quality under conventional and organic cropping systems applying two analytical approaches, Ecol. Indic., 13, 322-327, doi:10.1016/j.ecolind.2011.06.031, 2012.

Muckel, G. B. and Mausbach, M. J.: Soil quality information sheets, in: Methods for Assessing Soil Quality, edited by: Doran, J. W. and Jones, A. J., Soil Sci. Soc. Am., Special Publication 49, Madison, WI, 393-400, 1996.

Muller, G.: Index of geoaccumulation in sediments of the Rhine River, Geojournal, 2, 108-118, 1969. 
Murray, H., Pinchin, T. A., and Macfie, S. M.: Compost application affects metal uptake in plants grown in urban garden soils and potential human health risk, J. Soils Sediments, 11, 815-829, 2011.

Nadal, M., Schuhmacher, M., and Domingo, J. L.: Long-term environmental monitoring of persistent organic pollutants and metals in a chemical/petrochemical area: Human health risks, Environ. Pollut., 159, 1769-1777, 2001.

Nannipieri, P., Grego, S., and Ceccanti, B.: Ecological significance of the biological activity in soils, in: Soil Biochemical, edited by: Bollag, J. M. and Stotzky, G., Marcel Dekker, New York, 293355, 1990.

Nunes, J. S., Araújo, A. S. F., Nunes, L. A. P. L., Lima, L. M., Carneiro, R. F. V., Tsai, S. M., and Salviano, A. A. C.: Land degradation on soil microbial biomass and activity in Northeast Brazil, Pedosphere, 22, 88-95, 2012.

Pang, X. Y., Bao, W. K., and Zhang, Y. M.: Evaluation of Soil Fertility under different Cupressus chengiana forests using multivariate approach, Pedosphere, 16, 602-615, 2006.

Papa, S., Bartoli, G., Pellegrino, A., and Fioretto, A.: Microbial activities and trace element contents in an urban soil, Environ. Monit. Assess., 165, 193-203, 2010.

Parr, J. F., Papendick, R. I., Hornick, S., and Meyer, R. E.: Soil quality: Attributes and relationship to alternative and sustainable agriculture, Am. J. Alternative Agr., 7, 5-11, 1992.

Peijnenburg, W. J., Zablotskaja, M., and Vijver, M. G.: Monitoring metals in terrestrial environments within a bioavailability framework and a focus on soil extraction, Ecotox. Environ. Safe., 67, 163-79, 2007.

Pelfrêne, A., Waterlot, C., and Douay, F.: In vitro digestion and DGT techniques for estimating cadmium and lead bioavailability in contaminated soils: Influence of gastric juice $\mathrm{pH}$, Sci. Total Environ., 409, 5076-5085, 2011.

Pelfrêne, A., Douay, F., Richard, A., Roussel, H., and Girondelot, B.: Assessment of potential health risk for inhabitants living near a former lead smelter. Part 2: site-specific human health risk assessment of $\mathrm{Cd}$ and $\mathrm{Pb}$ contamination in kitchen gardens, Environ. Monit. Assess., 185, 2999-3012, 2013.

Poggio, L., Vrščaj,. B., Hepperle, E., Schulin, R., and Marsan, F. A.: Introducing a method of human health risk evaluation for planning and soil quality management of heavy metal-polluted soils - An example from Grugliasco (Italy), Landscape Urban Plan., 88, 64-72, 2008.

Pouyat, R. V., Yesilonis, I. D., Szlavecz, K., Csuzdi, C., Hornung, E., and Korsos, Z.: Response of forest soil properties to urbanization gradients in three metropolitan areas, Landscape Ecol., 23, 1187-1203, 2008.

Qi, Y., Darilek, J. L., Huang, B., Zhao, Y., Sun, W., and Gu, Z.: Evaluating soil quality indices in an agricultural region of Jiangsu Province, China, Geoderma, 149, 325-334, 2009.

Qin, H., Zhu, J., Liang, L., Wang, M., and Su, H.: The bioavailability of selenium and risk assessment for human selenium poisoning in high-Se areas, China, Environ. Int., 52, 66-74, 2013.

Qin, M. Z. and Zhao, J.: Strategies for sustainable use and characteristics of soil quality changes in urban-rural marginal area: a case study of Kaifeng, Acta Geogr. Sin., 55, 545-554, 2000 (in Chinese with English abstract).

Rafiq, M. T., Aziz, R., Yang, X., Xiao, W., Rafiq, M. K., Ali, B., and Li, T.: Cadmium phytoavailability to rice (Oryza sativa L.) grown in representative Chinese soils. A model to improve soil environmental quality guidelines for food safety, Ecotox. Environ. Safe., 103, 101-107, 2014.

Rahmanipour, F., Marzaiolib, F., Bahramia, H. A., Fereidounia, Z., and Bandarabadi, S. R.: Assessment of soil quality indices in agricultural lands of Qazvin Province, Iran, Ecol. Ind., 40, 1926, 2014.

Ramos, M. E., Benítez, E., García, P. A., and Robles, A. B.: Cover crops under different managements vs. frequent tillage in almond orchards in semiarid conditions: Effects on soil quality, App. Soil Ecol., 44, 6-14, 2010.

Reeves, D. W.: The role of organic matter in maintaining soil quality in continuous cropping systems, Soil Till. Res., 43, 131-167, 1997.

Rillig, M. C.: Arbuscular mycorrhyzae, glomalin, and soil aggregation, Can. J. Soil Sci., 84, 355-363, 2004.

Rodrigues, S., Pereira, M. E., Duarte, A. C., Ajmone-Marsan, F., Davidson, C. M., Grčman, H., Hossack, I., Hursthouse, A.S., Ljung, K., Martini, C., Otabbong, E., Reinoso, R., Ruiz-Cortés, E., Urquhart, G. J., and Vrščaj, B.: Mercury in urban soils: a comparison of local spatial variability in six European cities, Sci. Total Environ., 368, 926-936, 2006.

Rodrigues, S., Urquhart, G., Hossack, I.: Pereira, M. E., Duarte, A. C., and Davidson, C.: The influence of anthropogenic and natural geochemical factors on urban soil quality variability: a comparison between Glasgow, UK and Aveiro, Portugal, Environ. Chem. Lett., 27, 141-148, 2009.

Rodrigues, S. M., Cruz, N., Coelho, C., Henriques, B., Carvalho, L., Duarte, A. C., Pereira, E., and Römkens, A. M.: Risk assessment for $\mathrm{Cd}, \mathrm{Cu}, \mathrm{Pb}$ and $\mathrm{Zn}$ in urban soils: Chemical availability as the central concept, Environ. Pollut., 183, 234-243, 2013.

Rodríguez, M. D. F. and Lafarga, J. C. T.: Soil quality criteria for environmental pollutants, in: Encyclopedia of Environmental Health, edited by: Nriagu, J. O., Elsevier, 124-142, 2011.

Rousseau, L., Fonte, S. J., Téllez, O., Van der Hoek, R., and Lavelle, P.: Soil macrofauna as indicators of soil quality and land use impacts in smallholder agroecosystems of western Nicaragua, Ecol. Indic., 27, 71-82, 2013.

Ruiz, N., Jerome, M., Leonide, C., Christine, R., Gerard, H., Etienne, I., and Lavelle, P.: IBQS: A synthetic index of soil quality based on soil macro-invertebrate communities, Soil Biol. Biochem., 43, 2032-2045, 2011.

Sanchez, F. G., Carter, E. A., and Leggett, Z. H.: Loblolly pine growth and soil nutrient stocks eight years after forest slash Incorporation, Forest Ecol. Manage., 257, 1413-1419, 2009.

Santorufo, L., Van Gestel, C. A. M., and Maisto, G.: Ecotoxicological assessment of metal-polluted urban soils using bioassays with three soil invertebrates, Chemosphere, 88, 418-425, 2012a.

Santorufo, L., Van Gestel, C. A. M., Rocco, A., and Maisto, G.: Soil invertebrates as bioindicators of urban soil quality, Environ. Pollut., 161, 57-63, 2012b.

Sepehrnia, N., Mahboubi, A. A., Mosaddeghi, M. R., Safari Sinejani, A. A., and And Khodakaramian, G.: Escherichia coli transport through intact gypsiferous and calcareous soils during saturated and unsaturated flows, Geoderma, 217-218, 83-89, 2014.

Singh, A. K., Bordoloi, L. J., Kumar, M., Hazarika, S., and Parmar, B.: Land use impact on soil quality in eastern Himalayan region of India, Environ. Monit. Assess., 186, 2013-2024, 2014.

Sjöström, A. E., Collins, C. D., Smith, S. R., and Shaw, G.: Degradation and plant uptake of nonylphenol (NP) and nonylphenol- 
12-ethoxylate (NP12EO) in four contrasting agricultural soils, Envion. Pollut., 156, 1284-1289, 2008.

Sutherland, R. A.: Bed sediment-associated trace metals in an urban stream, Oahu, Hawaii, Environ. Geol., 39, 611-627, 2000.

Szolnoki, Z., Farsang, A., and Puskás, I.: Cumulative impacts of human activities on urban garden soils: Origin and accumulation of metals, Environ. Pollut., 177, 106-115, 2013.

Tischer, A., Blagodatskaya, E., and Hamer, U.: Extracellular enzyme activities in a tropical mountain rainforest region of southern Ecuador affected by low soil P status and land-use change, Appl. Soil Ecol., 74, 1-11, 2014.

Toledo, D. M., Galantini, J. A., Vazquez, S., and Arzuaga, S.: Soil organic carbon stock and stratification ratio as indicators of soil quality, 19th ISTRO International Soil Tillage Research Organization Conference and IV SUCS Meeting Striving for sustainable high productivity, 24-28 September 2012, Montevideo, Uruguay, Published on DVD, 2012.

Trasar-Cepeda, C., Leirós, C., Gil-Sotres, F., and Seoane, S.: Towards a biochemical quality index for soils: an expression relating several biological and biochemical properties, Biol. Fert. Soils, 26, 100-106, 1998.

Veum, K. S., Goyne, K. W., Kremer, R., Miles, R. J., and Sudduth, K. A.: Biological indicators of soil quality and soil organic matter characteristics in an agricultural management continuum, Biogeochemistry, 117, 81-99, 2014.

Voidarou, C., Bezirtzoglou, E., Alexopoulos, A., Plessas, S., Stefanis, C., Papadopoulos, I., Vavias, S., Stavropoulou, E., Fotoua, K., Tzora, A., and Skoufos, I.: Occurrence of Clostridium perfringens from different cultivated soils, Anaerobe, 17, 320-324, 2011.

Vrscaj, B., Poggio, L., and Marsan, F. A.: A method for soil environmental quality evaluation for managementand planning in urban areas, Landscape Urban Plan., 88, 81-94, 2008.

Wang, Q. and Wang, S.: Response of labile soil organic matter to changes in forest vegetation in subtropical regions, Appl. Soil Ecol., 47, 210-216, 2011.

Wenrui, Y., Rusong, W., Chuanbin, Z., and Feng, C.: Distribution and health risk assessment of organochlorine pesticides (OCPs) in industrial site soils: A case study of urban renewal in Beijing, China. J. Environ. Sci., 21, 366-372, 2009.
Wong, C. S. C., Li, X., and Thornton, I.: Urban environmental geochemistry of trace metals, Environ. Pollut., 142, 1-16, 2006.

Zhang, G. L., Zhu, Y. G., and Fu, B. J.: Quality changes of soils in urban and suburban areas and its eco-environmental impacts-a review, Acta Ecol. Sin., 23, 539-546, 2003.

Zhao, D., Li, F., Yang, Q., Wang, R., Song, Y., Tao, Y.: The influence of different types of urban land use on soil microbial biomass and functional diversity in Beijing, China, Soil Use Manage., 29, 230-239, 2013.

Zhao, F., Yang, G., Han, X., Feng, Y., and Ren, G.: Stratification of Carbon Fractions and Carbon Management Index in Deep Soil Affected by the Grain-to- Green Program in China, PLOS ONE, 9, e99657, 2014

Zhao, H., Xia, B., Fan, C., Zhao, P., and Shen, S.: Human health risk from soil heavy metal contamination under different land uses near Dabaoshan Mine, Southern China, Sci. Total Environ., 417-418, 45-54, 2012.

Zornoza, R., Mataix-Solera, J., Guerrero, C., Arcenegui, V., Mayoral, A. M., Morales, J., and Mataix-Beneyto, J.: Soil properties under natural forest in the Alicante Province of Spain, Geoderma, 142, 334-341, 2007.

Zornoza, R., Mataix-Solera, J., Guerrero, C., Arcenegui, V., MataixBeneyto, J., and Gómez, I.: Validating the effectiveness and sensitivity of two soil quality indices based on natural forest soils under Mediterranean conditions, Soil Biol. Biochem., 40, 2079 2087, 2008a.

Zornoza, R., Guerrero, C., Mataix-Solera, J., Scow, K. M., Arcenegui, V., and Mataix-Beneyto, J.: Near infrared spectroscopy for determination of various physical, chemical and biochemical properties in Mediterranean soils. Soil Biol. Biochem., 40, 1923-1930, 2008b.

Zornoza, R., Guerrero, C., Mataix-Solera, J., Scow, K. M., Arcenegui, V., and Mataix-Beneyto, J.: Changes in soil microbial community structure following the abandonment of agricultural terraces in mountainous areas of Eastern Spain, Appl. Soil Ecol., 42, 315-323, 2009. 